AperTO - Archivio Istituzionale Open Access dell'Università di Torino

\title{
A Simple Score, Based On Geriatric Assessment, Improves Prediction of Survival, and Risk Of Serious Adverse Events In Elderly Newly Diagnosed Multiple Myeloma Patients
}

\section{This is the author's manuscript}

Original Citation:

\section{Availability:}

This version is available http://hdl.handle.net/2318/1617581

since 2016-11-28T14:31:54Z

Terms of use:

Open Access

Anyone can freely access the full text of works made available as "Open Access". Works made available under a Creative Commons license can be used according to the terms and conditions of said license. Use of all other works requires consent of the right holder (author or publisher) if not exempted from copyright protection by the applicable law. 


\section{A simple score, based on geriatric assessment, improves prediction of survival, and risk of serious adverse events in elderly newly diagnosed multiple myeloma patients.}

Alessandra Larocca, MD1*, Sara Bringhen, MD1*, Andrea Evangelista, BSc, MSc2*, Massimo Offidani, MD3*, Stelvio Ballanti, MD3*, Alfonso Zaccaria, MD3*, Norbert Pescosta, MD3*, Vittorio Montefusco, MD3*, Luca De Rosa, MD3*, Angelo Michele Carella, MD3*, Luca Baldini, MD3*, Massimo Aglietta, MD3*, Vincelli lolanda Donatella, MD3*, Roberto Marasca, MD3*, Sara Pezzati, MD3*, Patrizia Tosi, MD3*, Federica Cocito, MD3*, Mariella Grasso, MD3*, Giuseppe Fioritoni, MD3*, Vincenzo Pavone3, Pellegrino Musto, MD3*, Sara Grammatico, MD3*, Paola Omedè, PhD1*, Francesca Gay, MD1*, Giovannino Ciccone, MD, PhD2*, Mario Boccadoro, MD1* and Antonio Palumbo, MD1

1Myeloma Unit, Division of Hematology, University of Torino, Torino, Italy; 2Unit of Cancer Epidemiology, University of Torino and CPO Piemonte, A.O. Città della Salute e della Scienza di Torino, Torino, Italy; 3Italian Multiple Myeloma Network, GIMEMA, Italy.

Background Elderly multiple myeloma (MM) patients are an heterogeneous population. Aging is associated with an increased frequency of co-morbidities, frailty and disability, with negative impact on treatment tolerance and outcome. A simple and reliable scoring system, based on geriatric assessment, has been developed to predict survival and used also to predict the risk of severe toxicities or treatment discontinuation in elderly newly diagnosed MM patients treated with lenalidomide-, bortezomib- or carfilzomib-based induction regimens.

Methods Patients with newly diagnosed $\mathrm{MM}$, ineligible for high-dose therapy and autologous stem cell transplantation due to age ( $\geq 65$ years) or coexisting co-morbidities, enrolled in 3 prospective multicenter trials, were included in the analysis. Up-front dose reductions were performed according to patients age (full doses for patients $\leq 75$ years and reduced for patients $>75$ years). Details on treatment regimens and results of these studies have previously been reported (Gay F et al EHA 2013, Larocca A et al EHA 2013, Bringhen $S$ et al EHA 2013). At diagnosis, a geriatric assessment had been performed, to assess co-morbidities, cognitive and physical conditions.

Results 869 patients were included in the analysis: 659 enrolled in the lenalidomidebased, 152 in the bortezomib-based and 58 in the carfilzomib-based trial. Median age was 74 years, and $44 \%$ of patients were older than 75 years. Median follow-up was 18 months. In univariable analysis, the risk of death was higher in patients aged 75-80 (Hazard Ratio, HR 1.37, $p=0.11$ ), and in patients older than 80 years (HR 2.75, $p<0.001$ ), compared to patients younger than 75 years. Performance status and gender did not significantly impact overall survival (OS). In a multivariable Cox model, an additive scoring system (range 0-5), based on age, co-morbidities, cognitive and physical conditions, was categorized to identify 3 groups: fit (score=0, 39\%); unfit (score=1, 31\%), and frail (score $\geq 2,30 \%$ ). The 18 -month OS was $92 \%, 88 \%$ and $73 \%$ in the three categories (fit, unfit and frail), respectively.

In a Cox's model, including ISS, gender and performance status, the HR compared to the fit category was $1.4(p=0.18)$ and $2.9(p<0.001)$ in unfit and frail patients. The cumulative 6 -month risk of serious adverse events or treatment discontinuation was $44 \%, 47 \%$ and 
$55 \%$ in fit, unfit and frail patients, respectively. The higher mortality rate in unfit and frail patients seems mainly due to higher cumulative incidence of grade $\geq 3$ adverse events (in particular extra hematologic toxicities) causing subsequent treatment discontinuation.

Conclusions The use of a simple scoring system, based on geriatric assessment, allows the identification of groups of patients with different survival and risk of severe toxicities.

Figure. Overall survival and crude Hazard Ratio for fit, unfit and frail patients.

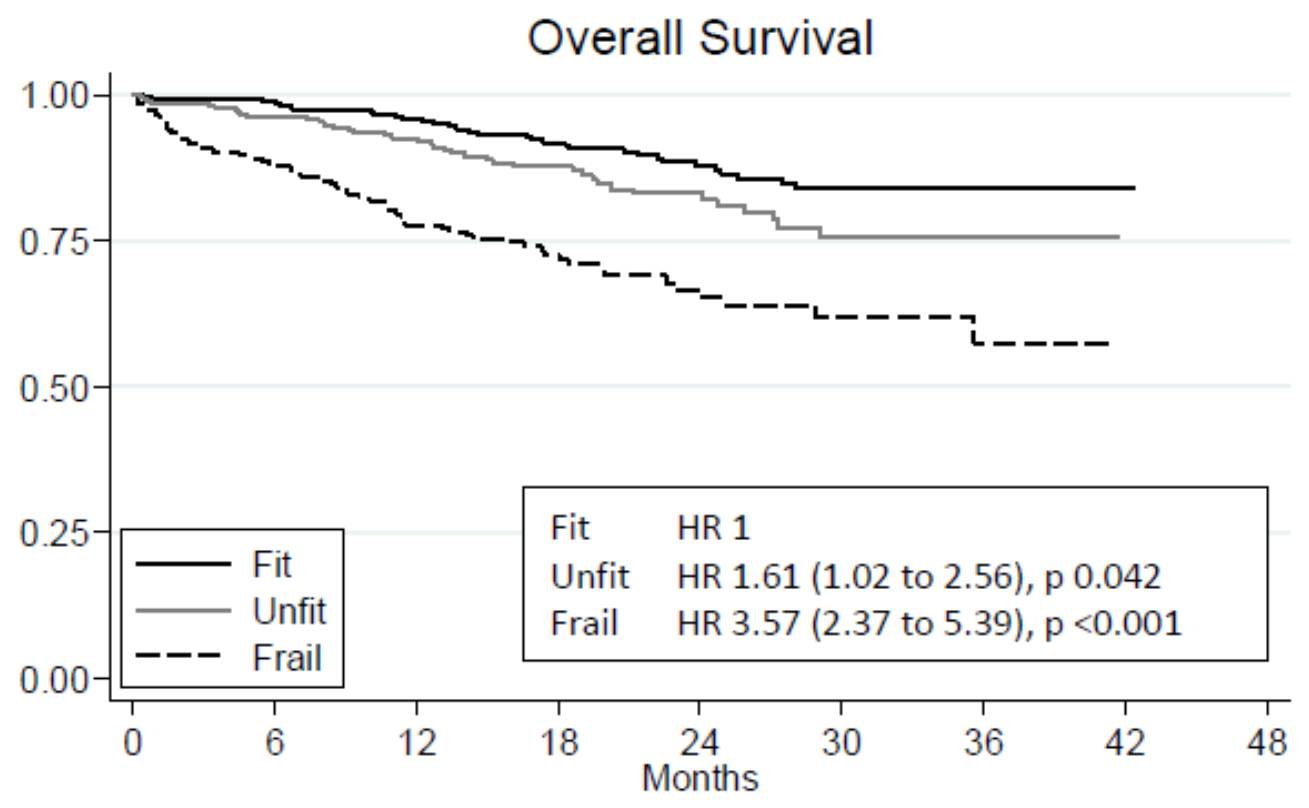

